\title{
Evaluation of some Sweet Corn Hybrids for Agronomic Traits and Technological Parameters under different Planting Dates
}

\author{
Ibrahim, A. I. A. ${ }^{1}$ and Ghada, A. Alfauomy ${ }^{2 *}$ \\ ${ }^{1}$ Department of, Maize Research Department, Field Crops Research Institute, Agricultural Research Center, Giza, Egypt \\ ${ }^{2}$ Department of Crops Technology Research, Food Technology Research Institute, Agricultural Research Center, Giza, Egypt
}

Received: $12 / 10 / 2019$

\begin{abstract}
Sweet corn is planted for using as fresh and processing at local market. Two field experiments were investigated at Agricultural Research Center (ARC) Station during the two seasons (2016 and 2017). In the first experiment interested on evaluation the total soluble solids (TSS) and total sugar (TS) content in 17 sweet corn hybrids. In the second experiment, the highest three crosses value of (TSS and total sugars) were selected and in the second season were grown under three planting dates (D1: March 21 ${ }^{\text {st }}, \mathrm{D} 2$ : May, $23^{\text {rd }}$ and D3: Aug., $22^{\text {nd }}$ ) to evaluate the effect of the planting date on sweet corn growth, yield and its quality parameters in fresh and processed product. Quality parameters for the first season (TSS and TS content) showed significant differences among 17 hybrids. The hybrids named $\mathrm{Gz} 3 \mathrm{~B} \times \mathrm{Gz} 15, \mathrm{Gz} 3 \mathrm{~B} \times \mathrm{Gz} 20$ and $\mathrm{Gz} 20 \times \mathrm{Gz} 10$ had the highest values of TSS and TS (16.06, 17.19 and 17.43\%) and (5.46, 5.76 and 6.84\%), respectively. In the second experiment, the grain yield, ear length and diameter, showed the highest values recorded at Aug $22^{\text {nd }}$ planting date. The highest values of TSS and TS were observed at Aug $22^{\text {nd }}$ after 20 days from pollination for the three selected sweet corn hybrids, which a decrease at the $3^{\text {rd }}$ harvest date after 26 days from pollination. A reduction in lightness values was observed as the harvest date increased. Total carotenoids content increased by increasing the harvest date and the highest content found at the third planting date (Aug $22^{\text {nd }}$ ) for $\mathrm{Gz} 3 \mathrm{~B} \times \mathrm{Gz} 20$ and Gz20 $\times \mathrm{Gz} 10$ hybrids. Cooking of the Gz3B $\times \mathrm{Gz} 20$ and Gz20 $\times \mathrm{Gz} 10$ hybrids showed higher sensory characteristics than corresponding Gz3B $\times$ Gz15 hybrid. No significant differences between two hybrids $(\mathrm{Gz} 3 \mathrm{~B} \times \mathrm{Gz} 20$ and Gz20×Gz10) in overall acceptability during storage for 9 months at $-18^{\circ} \mathrm{C} \pm 2$. The highest decrease in total sugars content during storage was found in the Gz3b $\times$ Gz15 hybrid.
\end{abstract}

Keywords: Sweet corn, Agronomic traits, Technological parameters, Sensory characteristics.

\section{INTRODUCTION}

Sweet corn is a cultivated plant for human consumption either fresh or processed throughout the world. It is an important source for fiber, minerals and certain vitamins (Sadaiah et al., 2013; Lertrat and Pulam, 2007). Although it has been cultivated on small areas in Egypt but, the expansion of cultivated areas is expected due to the increased in usage. It is mutation of field corn at the sugary $(\mathrm{Su})$ locus located in the short arm of chromosome 4 (Lee et al., 2006; Shin et al., 2006; Sa et al., 2012; Hossain et al., 2015). This mutation affects endosperm composition by causing it to accumulate twice as much sugar and eight to ten times more water-soluble polysaccharides than the field corn at the milky stage of endosperm development (Pajic et al., 2008; Jelena Srdic et al., 2016). Kernel quality can be determined using visual evaluation (shape, size...., etc.) and analytical evaluation as well as physical and mechanical properties estimation (Korunic et al., 1996).

Sweet corns can be classified into four basic groups: standard or sugary $(S u)$, super sweet or shrunken (Sh2), sugary enhanced ( $\mathrm{Se}$ ), and synergistic (Scott and Eldridge, 2005). Sweet corn is a high source of zeaxanthin. Zeaxanthin and lutein, are the major carotenoids contributing to the characteristic color of sweet corn. For a human health, these two carotenoids are improved the visual acuity. They act as antioxidants and as blue light eye filters, protecting ocular tissues from phototoxic damage. The carotenoids contents depend on plant cultivars (Scott and Eldridge, 2005). As humans cannot synthesize these compounds, they must be accumulated from dietary components containing zeaxanthin and lutein (Luana et al., 2017).

Cooking methods affect both physical and chemical changes resulting in an increase or decrease in phytochemical contents, particularly antioxidants present in plants (Turkmen et al., 2005). It has been reported that the thermal processing increases the bioactive contents and total antioxidant activity of tomatoes and sweet corn (Dewanto et al., 2002).

One of the goals of sweet corn producers is to produce sweet corn with a high quality. The quality of fresh or processed whole kernels, canned or frozen, is determined by its unique combination of flavor, texture and aroma (Lertrat and Pulam, 2007). Sweet corn has become more and more important. Its taste and nutritional value has made it a valued crop in all countries, Sweetness is the major component of sweet corn that affected by the amounts of sugar and starch in the endosperm. It has been reported that selection for more tender and crispy genotypes with a higher sugar and lower starch concentration and an increased sweet corn aroma would increase the eating quality of the product (Azanza et al., 1996).

Processing of corn is used to increase its shelf life but as a consequence, a significant loss of nutrients may occur via heat degradation or leaching (Hale et al., 2005). Sweet corn for processing is picked at different stages of maturity depending on the way it is to be processed. The corn for freezing is harvested at about the same stage as that for fresh market, while the corn for the whole kernel pack and the cream-style is harvested at a slightly later stage of maturity. Sweetness 
is determined not only by genetics, but also by the way the respective varieties are managed and harvested. Primary differences among the hybrid varieties include the duration of their vegetation period, content of sugars and suitability for various uses. The sugar content of fresh kernels was higher than other treatments (frozen and canned) for all varieties (Alan et al., 2014).

The aim of this study was to determine the influence of planting and harvest date on sweet corn yield as well as physico-chemical and technological characteristics of the fresh and frozen stored product.

\section{MATERIALS AND METHODS}

\section{Plant material and experimental design:}

Two field experiments were carried out at Agricultural Research Center at Giza Station during 2016 and 2017 grown seasons. In the first breeding experiment, 17 yellow sweet corn hybrids which developed at Giza Station were evaluated for total soluble solids (TSS) and total sugars (TS) content to select the best hybrids which were used to evaluate in the second experiment. In the second experiment, the three cross hybrids which the highest values of TSS and TS and grown under different planting dates (D1: March, 21 ${ }^{\text {st }}$, D2: May, 23 ${ }^{\text {rd }}$ and D3: Aug, 22 ${ }^{\text {nd }}$ ) and harvest dates (after 20, 23 and 26 days from pollination) to evaluate the effect of planting and harvest date on sweet corn establishment, growth, yield and its quality and technological parameters. The experiment designed as a randomized complete block design with three replications while factorial treatments arrangement replicated three times where planting dates and hybrid types were factorial analysed where treatments plot size consisted of one row, $70 \mathrm{~cm}$ apart and $6 \mathrm{~m}$ long and 15 $\mathrm{cm}$ between plants at two experiments. At maturity, the numbers of days until $50 \%$ silking and teaseling, plant and ear heights were recorded on 10 randomly selected plants of each plot. At fresh market stage maturity, all ears were harvested and weighted to estimate grain yield then after harvest, 5 ears were randomly taken for plot to determine grain yield components i.e. ear length, ear diameter, number of rows/ear and number of kernel. Then these ears were used to evaluate the quality and technological parameters for each selected hybrid.

\section{Analytical methods: \\ Quality parameters determination:}

Total soluble solids (TSS) were measured by A Digital Refractometer (Portable Refractometer RHB 032) according to the method of Alan et al., (2014). Moisture and total sugar content of sweet corn ware determined according to the method described in AOAC (2005). Identification of sugars by YL9100 HPLC system with a RI-(Refractive Index) detector was carried out (Nunes et al., 2013). Starch content was estimated by the method of Jarvis and Walker (1993). The procedure for carotenoids determination used was based on an Approved Method (AACC 2000). The color of sweet corn was measured according to the method outlined by McGurie (1992). Weight loss of ears during storage was determined according to Shao and Li (2011)

\section{Technological evaluation}

\section{Blanching and Freezing process:}

The ears of sweet corn were blanched in boiling water for $3 \mathrm{~min}$ in a stainless-steel pot and cooled. The blanched corns were packed in polyethylene bags and frozen at $-18 \pm 2^{\circ} \mathrm{C}$ for 9 months, to evaluate the effect of frozen storage on the ears quality (Junpatiw et al., 2013).

\section{Cooking process}

The ears were boiled for $5 \mathrm{~min}$ to obtain clear transparent texture indicating a well-done cooking (Junpatiw et al., 2013).

\section{Sensory evaluation:}

Ears at zero time were cooked and immediately organoleptically evaluated for their sensory characteristics (appearance, color, flavor, taste and overall acceptability). Each sample was served to welltrained ten panelists $(\mathrm{n}=10)$ of Food Technology Research Institute, Agriculture Research Centre, Giza, Egypt to carry out the sensory evaluation test for the tested attributes. All attributes were measured using a hedonic scale from 0 to 9 , where a score of 9 represents excellent and a score of zero represents the lowest quality level (Shao and Li, 2011). Overall acceptability was evaluated during storage.

\section{Statistical Analysis}

The collected date was analyzed with the analysis of variance (ANOVA) model. The companies of means was conducted using LSD test at a significant level of $p$ $=0.05$ for morphological, yield and its components traits. While for quality and technology traits, the collected date were statistically analyzed for mean values and standard deviation using the SAS (1987). The obtained data were subjected to one-way analysis of variance (ANOVA) at $P=0.05$ followed by Duncan's new multiple range tests to assess differences between samples mean.

\section{RESULTS AND DISCUSSION}

The results of the 17 sweet corn hybrids evaluation in the first season with respect to total soluble solids (TSS) and total sugar contents are presented in Table (1). Statistical analysis of the data showed significant differences among the tested sweet corn hybrids for two traits. TSS contents of the sweet corn hybrids ranged from 12.10 to $17.43 \%$. The highest value was observed in Gz20×Gz10 hybrid while, Gz4 $\times \mathrm{Gz} 17$ hybrid recorded the lowest value for this trait. Total sugar content showed significant differences among the 17 hybrids of sweet corn, where the highest level of total sugar content was exhibited for Gz20 $\times$ Gz10 hybrid (6.84\%) and the lowest content was detected in $\mathrm{Gz} 4 \times \mathrm{Gz} 17$ hybrid (2.24\%). 
Table (1): Total soluble solids (TSS) and total sugar content ( $\%$ as the wet basis) of fresh sweet corn kernels

\begin{tabular}{|c|c|c|}
\hline Hybrids & TSS \% & Sugar Content \% \\
\hline Gz $1 \times$ Gz 4 & $14.00 \mathrm{~h}^{\mathrm{i}} \pm 0.00$ & $3.175^{\mathrm{k}} \pm 0.08$ \\
\hline Gz $1 \times$ Gz 15 & $14.15^{\mathrm{h}} \pm 0.21$ & $3.41^{\mathrm{j}} \pm 0.01$ \\
\hline Gz $1 \times$ Gz 17 & $13.90^{\mathrm{ij}} \pm 0.14$ & $3.35^{\mathrm{j}} 0.00$ \\
\hline $\mathbf{G z} 3 \mathrm{~A} \times \mathbf{G z} 4$ & $15.08^{\mathrm{f}} \pm 0.11$ & $4.68^{\mathrm{f}} \pm 0.03$ \\
\hline Gz $3 A \times G z 6$ & $15.86^{\mathrm{cd}} \pm 0.08$ & $5.07^{\mathrm{d}} 0.05$ \\
\hline Gz $3 A \times$ Gz 15 & $14.50^{\mathrm{g}} \pm 0.14$ & $3.8^{\mathrm{h}} \pm 0.00$ \\
\hline Gz $3 A \times$ Gz 20 & $15.50^{\mathrm{e}} \pm 0.00$ & $4.47^{\mathrm{g}} \pm 0.04$ \\
\hline Gz 3B $\times$ Gz 10 & $15.00^{\mathrm{f}} \pm 0.00$ & $2.96^{1} \pm 0.10$ \\
\hline Gz 3B $\times$ Gz 15 & $16.06^{\mathrm{c}} \pm 0.08$ & $5.46^{\mathrm{c}} \pm 0.02$ \\
\hline Gz 3B $\times$ Gz 20 & $17.19^{\mathrm{b}} \pm 0.01$ & $5.76^{\mathrm{b}} \pm 0.08$ \\
\hline Gz $4 \times$ Gz 5 & $13.74^{\mathrm{j}} \pm 0.05$ & $3.64^{\mathrm{i}} \pm 0.01$ \\
\hline Gz $4 \times$ Gz 10 & $15.74^{\mathrm{d}} \pm 0.09$ & $5.00^{\mathrm{d}} \pm 0.00$ \\
\hline Gz 4×Gz 6 & $13.50^{\mathrm{k}} \pm 0.00$ & $3.10^{\mathrm{k}} \pm 0.04$ \\
\hline Gz $4 \times$ Gz 15 & $15.04^{\mathrm{f}} \pm 0.12$ & $4.38^{\mathrm{g}} \pm 0.02$ \\
\hline Gz 4×Gz 17 & $12.10^{1} \pm 0.14$ & $2.24^{1} \pm 0.11$ \\
\hline Gz $5 \times$ Gz 10 & $15.75^{\mathrm{d}} \pm 0.07$ & $4.88^{\mathrm{e}} \pm 0.00$ \\
\hline Gz $20 \times \mathbf{G z} 10$ & $17.43^{\mathrm{a}} \pm 0.11$ & $6.84^{\mathrm{a}} \pm 0.01$ \\
\hline
\end{tabular}

Mean values followed by different superscripts (within the same column) are significantly different at the 5\%. Values are the average of 3 experiments $\pm \mathrm{SD}$

Based on these finding, three hybrids, named $\mathrm{Gz} 3 \mathrm{~B} \times \mathrm{Gz} 15, \mathrm{Gz} 3 \mathrm{~B} \times \mathrm{Gz} 20$ and $\mathrm{Gz} 20 \times \mathrm{Gz} 10$, which exhibited the highest content for total soluble solids $\%$ and total sugar content \% were selected in the second season to study the effect of harvest dates and hybrid types on the grain yield and its components in addition to some quality and technology attributes.

\section{Agronomy parameters:}

The results of analysis of variance for all studied traits (Table 2) showed the significant effects of date planting values for all studied traits except for test trait, which did not affect by planting dates (Table 2). Significantly differences was observed among hybrids for grain yield, ear diameter and test traits, whereas, the interaction between hybrids and dates was highly significant for grain yield and testing traits, indicating the hybrids exhibited the same rank cross the three dates and exhibited the same responses to the three planting dates for all studied traits, except the two mentioned traits.
Determination of planting date for sweet corn hybrids is very necessary for high performance for yield and other agronomic traits. According to the results in Table (3), which explained the effects of planting date on all studied traits, the best planting date was the third date (22 Aug.) followed by the first date (21 March) for yield and its components. While, the second date was worst date to planting sweet corn hybrids, except for No. of rows/ear. No. of days from planting to $50 \%$ silking and teaseling were not significantly affected by the planting date, while for plant and ear heights, the first date (21 March) was the best sowing date for these traits.. Test trail, also, was not affected by planting date, there was no significant difference among the three dates. Results in Table (3), also, revealed that, no significant differences was observed among the three hybrids for all traits, except for test trait, whereas the third hybrid exhibited the highest significant value when compared with the other two hybrids. 
Table (2): Analysis of variance for grain yield, ear length, ear diameter, number of rows/ear, number of kernels/row, days to $50 \%$ Silking, plant height, ear height and testing of sweet corn hybrids affected by planting dates

Mean square

\begin{tabular}{|c|c|c|c|c|c|c|c|c|c|c|c|}
\hline S.O & D.F. & $\begin{array}{l}\text { Grain } \\
\text { Yield }\end{array}$ & $\begin{array}{c}\text { Ear } \\
\text { length }\end{array}$ & $\begin{array}{c}\text { Ear } \\
\text { diameter }\end{array}$ & $\begin{array}{c}\text { No of } \\
\text { rows/ear }\end{array}$ & $\begin{array}{c}\text { No of } \\
\text { kernels } \\
\text { /row }\end{array}$ & $\begin{array}{c}50 \% \\
\text { Silking }\end{array}$ & $\begin{array}{c}\mathbf{5 0} \% \\
\text { Tasseling }\end{array}$ & $\begin{array}{l}\text { Plant } \\
\text { height }\end{array}$ & $\begin{array}{c}\text { Ear } \\
\text { height }\end{array}$ & $\begin{array}{c}\text { Testi } \\
\text { ng }\end{array}$ \\
\hline Date (D) & 2 & $7662.7 * *$ & $31.1 * *$ & $0.8^{* *}$ & $4.66^{*}$ & $294.1 * *$ & $7.1^{*}$ & 5.15 & $1640.2 * *$ & $250.9 * *$ & 0.7 \\
\hline D (REP) & 6 & 126.82 & 0.73 & 0.07 & 0.81 & 7.86 & 1.5 & 1.56 & 33.1 & 10.7 & 0.4 \\
\hline $\begin{array}{c}\text { Hybrids } \\
\text { (H) }\end{array}$ & 2 & 325.2 & 0.18 & 0.11 & 0.45 & 5.67 & 0.04 & 0.04 & 258.8 & 18.04 & $2.9 * *$ \\
\hline D $\times H$ & 4 & $848.4 * *$ & 3.4 & 0.06 & 1.49 & 26.6 & 1.5 & 2.15 & 13.04 & 7.9 & $1.1^{* *}$ \\
\hline Error & 12 & 134.6 & 1.8 & 0.05 & 0.98 & 19.6 & 2.02 & 1.28 & 230.07 & 172.4 & 0.1 \\
\hline CV\% & & 7.7 & 7.2 & 5.49 & 6.67 & 12.2 & 2.3 & 1.76 & 8.2 & 14.8 & 16.6 \\
\hline
\end{tabular}

$*, * *$ significant at 0.05 and 0.01 levels of probability, respectively

Table (3): Effect of planting dates and sweet corn hybrids on grain yield, ear length, ear diameter, number of rows/ear, number of kernels/rows, days to $50 \%$ Silking, plant height, ear height and test

\begin{tabular}{|c|c|c|c|c|c|c|c|c|c|c|}
\hline Treatment & $\begin{array}{l}\text { Grain } \\
\text { Yield }\end{array}$ & $\begin{array}{c}\text { Ear } \\
\text { length }\end{array}$ & $\begin{array}{c}\text { Ear } \\
\text { diameter }\end{array}$ & $\begin{array}{c}\text { No of } \\
\text { rows/ear }\end{array}$ & $\begin{array}{c}\text { No of } \\
\text { kernel } \\
\text { s/row } \\
\end{array}$ & $\begin{array}{c}\mathbf{5 0 \%} \\
\text { Silking }\end{array}$ & $\begin{array}{c}\mathbf{5 0} \% \\
\text { Tasseling }\end{array}$ & $\begin{array}{c}\text { Plant } \\
\text { height }\end{array}$ & $\begin{array}{c}\text { Ear } \\
\text { height }\end{array}$ & Test \\
\hline & \multicolumn{10}{|c|}{ Dates } \\
\hline Date 1 & 149.4 & 19.1 & 3.9 & 14.2 & 40.3 & 60.8 & 63.4 & 197.8 & 93.6 & 2.5 \\
\hline Date 2 & 121.0 & 16.8 & 3.6 & 15.6 & 29.7 & 61.8 & 64.5 & 184.3 & 88.1 & 2.3 \\
\hline Date 3 & 179.3 & 20.5 & 4.3 & 14.6 & 38.7 & 62.6 & 64.8 & 170.8 & 83.1 & 2.8 \\
\hline \multirow[t]{2}{*}{ LSD 0.05 (D) } & 12.9 & 0.9 & 0.3 & 1.0 & 3.2 & 1.4 & 1.4 & 6.6 & 3.7 & 0.7 \\
\hline & \multicolumn{10}{|c|}{ Hybrids } \\
\hline Gz 3B $\times$ Gz 15 & 150.8 & 18.9 & 4.0 & 15.0 & 36.5 & 61.7 & 64.3 & 178.4 & 86.6 & 2.4 \\
\hline Gz 3B×Gz 20 & 143.5 & 18.6 & 3.8 & 14.8 & 36.9 & 61.7 & 64.2 & 185.7 & 89.2 & 2.1 \\
\hline Gz 20×Gz 10 & 155.4 & 18.8 & 3.9 & 14.6 & 35.3 & 61.8 & 64.3 & 188.8 & 89.0 & 3.2 \\
\hline LSD 0.05 (H) & 11.9 & 1.4 & 0.2 & 1.0 & 4.5 & 1.4 & 1.1 & 15.5 & 13.4 & 0.4 \\
\hline
\end{tabular}


The interaction effects of date planting and sweet corn hybrids for all studied traits are presented in Table (4). Depending on the best planting date (22 Agu.), the highest mean value for grain yield was recorded for hybrid $\mathrm{Gz} 20 \times \mathrm{Gz} 10$ when planting at $22 \mathrm{Agu}$. Followed by $\mathrm{Gz} 3 \mathrm{~B} \times \mathrm{Gz} 20$ then $\mathrm{Gz} 3 \mathrm{~B} \times \mathrm{Gz} 15$ at the same date. While, the lowest value observed for hybrid $\mathrm{Gz} 3 \mathrm{~B} \times \mathrm{Gz}$ 20 when planted at 23 May. The same trend was observed for two trails i.e. ear length and ear diameter, these results explain that, planting sweet corn hybrid on 23 May was associated with lower yield ear length and ear diameter. The three hybrids did not differ significantly among them for these two traits at each date. Whereas, the value of these traits was significantly increased at $22 \mathrm{Agu}$. from than other two planting dates.

Table (4): Interaction effect of planting dates, and hybrids in 2017 growing seasons

\begin{tabular}{|c|c|c|c|c|c|c|c|c|c|}
\hline \multirow{3}{*}{ Hybrids } & \multicolumn{9}{|c|}{ Planting Dates } \\
\hline & \multicolumn{3}{|c|}{ Yield } & \multicolumn{3}{|c|}{ Ear length $\mathrm{cm}$} & \multicolumn{3}{|c|}{ Ear diameter $\mathrm{cm}$} \\
\hline & $\begin{array}{c}\text { March, } \\
21\end{array}$ & $\begin{array}{c}\text { May, } \\
23\end{array}$ & $\begin{array}{c}\text { Aug., } \\
22\end{array}$ & $\begin{array}{c}\text { March, } \\
21\end{array}$ & $\begin{array}{c}\text { May, } \\
23\end{array}$ & $\begin{array}{c}\text { Aug., } \\
22\end{array}$ & $\begin{array}{c}\text { March, } \\
21\end{array}$ & $\begin{array}{c}\text { May, } \\
23\end{array}$ & $\begin{array}{c}\text { Aug., } \\
22\end{array}$ \\
\hline Gz $3 B \times G z 15$ & 140.67 & 133.11 & 159.17 & 18.55 & 17.33 & 21.00 & 4.00 & 3.97 & 4.31 \\
\hline $\mathbf{G z} 3 \mathbf{B} \times \mathbf{G z} 20$ & 161.67 & 109.67 & 178.89 & 19.00 & 15.78 & 21.28 & 3.90 & 3.44 & 4.28 \\
\hline Gz 20×Gz 10 & 146.00 & 120.22 & 200.00 & 19.78 & 17.44 & 20.33 & 4.01 & 3.63 & 4.33 \\
\hline LSD 0.05 & \multicolumn{3}{|c|}{$\begin{array}{c}\mathrm{D}=12.99, \underset{=20.64}{\mathrm{Hy}}=11.92, \mathrm{D} \times \mathrm{Hy} \\
\end{array}$} & \multicolumn{3}{|c|}{$\begin{array}{c}\mathrm{D}=0.99, \begin{array}{c}\mathrm{Hy} \\
=2.43\end{array} \\
=2.40, \mathrm{D} \times \mathrm{Hy}\end{array}$} & \multicolumn{3}{|c|}{$\begin{array}{c}\mathrm{D}=0.31, \mathrm{Hy}=0.23, \mathrm{D} \times \mathrm{Hy} \\
=0.40\end{array}$} \\
\hline
\end{tabular}

Planting Dates

\begin{tabular}{|c|c|c|c|c|c|c|c|c|c|}
\hline \multirow[t]{2}{*}{ Hybrids } & \multicolumn{3}{|c|}{ No. of rows/ear } & \multicolumn{3}{|c|}{ No. of kernels/row } & \multicolumn{3}{|c|}{$50 \%$ Silking } \\
\hline & $\begin{array}{l}\text { March, } \\
21\end{array}$ & $\begin{array}{c}\text { May, } \\
23\end{array}$ & $\begin{array}{c}\text { Aug., } \\
22\end{array}$ & $\begin{array}{l}\text { March, } \\
21\end{array}$ & $\begin{array}{c}\text { May, } \\
23\end{array}$ & $\begin{array}{c}\text { Aug., } \\
22\end{array}$ & $\begin{array}{l}\text { March, } \\
21\end{array}$ & $\begin{array}{c}\text { May, } \\
23\end{array}$ & Aug.,22 \\
\hline Gz $3 B \times G z 15$ & 14.22 & 16.67 & 14.33 & 39.00 & 29.78 & 40.72 & 61.00 & 62.00 & 62.33 \\
\hline $\mathbf{G z} 3 \mathrm{~B} \times \mathbf{G z} 20$ & 14.67 & 14.89 & 14.89 & 41.44 & 28.11 & 41.22 & 61.33 & 62.00 & 62.00 \\
\hline Gz 20×Gz 10 & 13.78 & 15.33 & 14.78 & 40.67 & 31.33 & 37.17 & 60.33 & 61.67 & 63.67 \\
\hline LSD 0.05 & \multicolumn{3}{|c|}{$\begin{array}{c}\mathrm{D}=1.04, \mathrm{Hy}=1.02, \mathrm{D} \times \mathrm{Hy} \\
=1.76\end{array}$} & \multicolumn{3}{|c|}{$\begin{array}{c}\mathrm{D}=3.23, \underset{\mathrm{Hy}}{=4.55}, \mathrm{D} \times \mathrm{Hy} \\
=7.88\end{array}$} & \multicolumn{3}{|c|}{$\begin{array}{c}\mathrm{D}=1.42, \mathrm{Hy}=1.46, \mathrm{D} \times \mathrm{Hy} \\
=2.53\end{array}$} \\
\hline
\end{tabular}

Planting Dates

\begin{tabular}{|c|c|c|c|c|c|c|c|c|c|c|c|c|}
\hline \multirow{2}{*}{ Hybrids } & \multicolumn{3}{|c|}{$50 \%$ Tasseling } & \multicolumn{3}{|c|}{ Plant height } & \multicolumn{3}{|c|}{ Ear height } & \multicolumn{3}{|c|}{ Test } \\
\hline & $\begin{array}{l}\text { Mar } \\
\text { ch, } \\
21\end{array}$ & $\underset{23}{\text { May, }}$ & Aug. & $\begin{array}{l}\text { March, } \\
21\end{array}$ & $\underset{23}{\text { May, }}$ & Aug., & $\begin{array}{l}\text { Marc } \\
\text { h, } 21\end{array}$ & $\underset{23}{\text { May, }}$ & Aug., & $\begin{array}{l}\text { March, } \\
21\end{array}$ & $\underset{23}{\text { May, }}$ & Aug., \\
\hline Gz $3 B \times G z 15$ & 63.6 & 64.6 & 64.6 & 190.3 & 178.3 & 166.6 & 90.3 & 86.3 & 82.3 & 2.6 & 1.6 & 3.0 \\
\hline Gz $3 B \times G z 20$ & 63.6 & 65.0 & 64.0 & 201.6 & 185.6 & 170.0 & 96.0 & 89.0 & 82.6 & 1.6 & 2.6 & 2.0 \\
\hline Gz $20 \times$ Gz 10 & 63.0 & 64.0 & 66.0 & 201.6 & 189.0 & 176.0 & 94.6 & 89.0 & 83.3 & 3.3 & 2.6 & 3.6 \\
\hline LSD 0.05 & \multicolumn{3}{|c|}{$\begin{array}{c}D=1.44, \text { Hy }=1.16 \\
\text { D x Hy }=2.01\end{array}$} & \multicolumn{3}{|c|}{$\begin{array}{c}D=6.65, H y=15.58, D \\
x \text { Hy }=26.98\end{array}$} & \multicolumn{3}{|c|}{$\begin{array}{c}\mathrm{D}=3.78, \mathrm{Hy}=13.49, \mathrm{D} \\
\times \text { Hy }=23.36\end{array}$} & \multicolumn{3}{|c|}{$\begin{array}{c}D=0.74, \mathrm{Hy}=0.45, \mathrm{D} \\
\text { x Hy }=0.78\end{array}$} \\
\hline
\end{tabular}

The highest number of rows/ear was obtained for Hybrid $\mathrm{Gz} 3 \mathrm{~B} \times \mathrm{Gz} 15$ at the second data (May, 23). The highest number of rows/ear also was observed for the same date for the three hybrids. Whereas, the lowest value for number of rows/ear was observed for hybrid Gz $20 \times \mathrm{Gz} 10$ at the first date (March, 21). It could be noted that, hybrid Gz $20 \times \mathrm{Gz} 10$ which had the highest significantly grain yield while did not exceeded in other traits of yield components. This may be attributed to increase for ear weight or No. of plants which carried two ears. With respect to agronomic traits i.e. No. of days from planting to $50 \%$ silking and teaseling and plant and ear heights, the three hybrids did not significantly differed among them for these traits. The earlier hybrid was $\mathrm{Gz} 20 \times \mathrm{Gz} 10$ at first and second planting date while it was lowest in flowering at third date, while, the greatest value for plant and ear highest were obtained for the $\mathrm{Gz} 20 \times \mathrm{Gz} 10$ hybrid compared 
with the other two hybrids for these traits. With respect of tasting traits, the best hybrid for this trait was hybrid $\mathrm{Gz} 20 \times \mathrm{Gz} 10$ followed by $\mathrm{Gz} 3 \mathrm{~B} \times \mathrm{Gz} 15$ at first and third planting date, but hybrid $\mathrm{Gz} 20 \times \mathrm{Gz} 10$ had superiority when compared with other two hybrids. The lowest value for this trait was observed for $\mathrm{Gz} 3 \mathrm{~B} \times \mathrm{Gz}$ 20 and $\mathrm{Gz} 3 \mathrm{~B} \times \mathrm{Gz} 15$ at first and second planting date, respectively.

In general, the present study revealed that both the planting date and the cultivar type had a significant effect on grain yield in applied sweet corn hybrid under the field conditions. Similar results were obtained by Abdul Rahman et al. (2001), Nielson et al. (2002) and Hamzeh et al. (2015).

\section{Moisture content}

Moisture content of sweet corn hybrids in the second season experiment was illustrated in Table (5). In the first planting date, results showed significant differences in moisture content. Delaying in harvest date caused a decrease in the moisture content. At the first harvest date (20 days after pollination), sweet corn kernels had the highest moisture content for the three studied hybrids relative to the tow other harvest dates. In the second planting date it was cleared that the first harvest date recorded the highest value of moisture content compared with the second and third harvest date, the $\mathrm{Gz} 3 \mathrm{~B} \times \mathrm{Gz} 15$ hybrid recorded the highest value $(72.49 \%)$. The same trend of results was found in the third planting date. It was observed that high values of moisture content were recorded in the third planting date at the three harvest date in the three hybrids of sweet corn compared with the first and the second planting date. In general, the best sweet corn planting and harvest date for moisture content were the third planting date (August) and the first harvest date (after 20 days of pollination). Same finding was observed by Szymanek (2009) who reported that the mean value of kernels moisture content decreased from 77.41 to 69.83 $\%$ at the first and fourth day of harvest, respectively. A similar decreasing in moisture content with increasing harvest maturity was detected. Kernel moisture content in sweet corn sh2 hybrids ranged from $73.1 \%$ to $76.8 \%$, suggesting that the hybrids varied in their rates of ear maturation (Kulvade and Chowladda, 1997).

Table (5): Moisture content (\% as wet basis) of fresh sweet corn hybrids at different planting and harvesting dates

\begin{tabular}{|c|c|c|c|}
\hline \multirow{3}{*}{ Hybrids } & \multicolumn{3}{|c|}{ Harvest date } \\
\hline & $1^{\text {st }}$ & $2^{\text {nd }}$ & $3^{\text {rd }}$ \\
\hline & \multicolumn{3}{|c|}{ First planting date (March) } \\
\hline Gz 3B $\times$ Gz 15 & $72.88^{\mathrm{d}}{ }_{\mathrm{a}} \pm 0.13$ & $63.95^{\mathrm{h}}{ }_{\mathrm{b}} \pm 0.07$ & $54.48{ }^{h}{ }_{c} \pm 0.06$ \\
\hline Gz 3B $\times$ Gz 20 & $71.74{ }_{\mathrm{a}}^{\mathrm{f}} \pm 0.28$ & $65.80{ }^{\mathrm{f}}{ }_{\mathrm{b}} \pm 0.04$ & $56.42{ }^{\mathrm{f}}{ }_{\mathrm{c}} \pm 0.14$ \\
\hline Gz 20×Gz 10 & $69.93{ }^{\mathrm{h}}{ }_{\mathrm{a}} \pm 0.04$ & $64.84^{g}{ }_{b} \pm 0.12$ & $56.35^{\mathrm{f}}{ }_{\mathrm{c}} \pm 0.11$ \\
\hline
\end{tabular}

Second planting date (May)

\begin{tabular}{|c|c|c|c|}
\hline $\mathbf{G z} 3 B \times G z 15$ & $72.49_{\mathrm{a}}^{\mathrm{e}} \pm 0.04$ & $66.79^{\mathrm{e}}{ }_{\mathrm{b}} \pm 0.04$ & $55.30^{\mathrm{g}}{ }_{\mathrm{c}} \pm 0.01$ \\
\hline Gz $3 B \times G z 20$ & $71.31_{\mathrm{a}}^{\mathrm{g}} \pm 0.04$ & $67.33^{d}{ }_{b} \pm 0.04$ & $56.58{ }^{\mathrm{e}} \pm 0.04$ \\
\hline Gz 20×Gz 10 & $69.33^{\mathrm{i}}{ }_{\mathrm{a}} \pm 0.09$ & $64.84^{\mathrm{g}}{ }_{\mathrm{b}} \pm 0.03$ & $59.88{ }^{d}{ }_{c} \pm 0.05$ \\
\hline
\end{tabular}

Third planting date (August)

\begin{tabular}{|c|c|c|c|}
\hline Gz $3 B \times G z 15$ & $76.82^{\mathrm{a}}{ }_{\mathrm{a}} \pm 0.06$ & $75.88^{a}{ }_{b} \pm 0.04$ & $72.11_{\mathrm{c}}^{\mathrm{c}} \pm 0.07$ \\
\hline Gz $3 B \times G z 20$ & $76.26^{b}{ }_{a} \pm 0.07$ & $75.06^{b}{ }_{b} \pm 0.08$ & $73.23^{a}{ }_{c} \pm 0.07$ \\
\hline Gz 20×Gz 10 & $74.49^{\mathrm{c}}{ }_{\mathrm{a}} \pm 0.017$ & $73.20^{c}{ }_{b} \pm 0.02$ & $72.90^{b}{ }_{c} \pm 0.02$ \\
\hline
\end{tabular}

Experience showed that sweet corn quality is very closely correlated with the moisture percentage and with postharvest grade evaluation (Szymanek, 2009). Sweet corn has a very short period of optimum harvest maturity, and its quality rapidly changes close to and following the peak. The highest quality cut from most of the standard sweet corn hybrids would be obtained at the kernel moisture level of 72 to $73 \%$. At 74 to $75 \%$ moisture content, the flavor and taste were good but the kernel size and uniformity, color, and cut-corn yield of the standard sweet hybrids might be below. At 70 to $71 \%$, the critical dividing point, the yield was higher but the cut corn would appear to be older (large; darker yellow kernels) and might be tougher (Szymanek, 2009). 


\section{Total soluble solids (TSS)}

Effect of planting and harvest date on the total soluble solids of sweet corn hybrids is displayed in Table (6). In the first planting date, TSS value decreased by delaying the harvesting date. High values of TSS were observed in Gz20 $\times$ Gz10 hybrid at the three harvest dates compared with the two other hybrids Gz3B $\times \mathrm{Gz} 15$ and $\mathrm{Ga} 3 \mathrm{~B} \times \mathrm{Gz} 20$. In the third planting date, the TSS values increased in the three hybrids compared with the first and second planting dates. Alan et al. (2014) found that, the soluble solid concentration of kernels of seven sweet corn varieties ranged from 16.3 to $27.4 \%$. TSS results reported are similar to those found by Hale et al. (2005). Kleinhenz, (2003) stated that the refractometer, which measures TSS, has been utilized as a rapid, preharvest method to determine sweet corn sugars content.

Table (6): Total soluble solids (TSS \%) content of sweet corn hybrids at different three planting dates and three harvesting dates

\begin{tabular}{|c|c|c|c|}
\hline \multirow{3}{*}{ Hybrids } & \multicolumn{3}{|c|}{ Harvest date } \\
\hline & $1^{\text {st }}$ & $2^{\text {nd }}$ & $3^{\text {rd }}$ \\
\hline & \multicolumn{3}{|c|}{ First planting date (March) } \\
\hline Gz 3B $\times$ Gz 15 & $16.00{ }^{\mathrm{f}}{ }_{\mathrm{a}} \pm 0.0$ & $14.50{ }_{b}^{f} \pm 0.00$ & $14.25_{\mathrm{c}}^{\mathrm{e}} \pm 0.07$ \\
\hline Gz 3B $\times \mathbf{G z} 20$ & $16.50{ }_{\mathrm{a}}^{\mathrm{def}} \pm 0.71$ & $15.40^{\mathrm{e}}{ }_{\mathrm{a}} \pm 0.14$ & $13.5_{\mathrm{b}}^{\mathrm{f}} \pm 0.71$ \\
\hline \multirow[t]{2}{*}{ Gz 20×Gz 10} & $17.25^{\mathrm{bcd}} \pm 0.35$ & $17.50^{\mathrm{a}}{ }_{\mathrm{a}} \pm 0.28$ & $15^{\mathrm{d}}{ }_{\mathrm{b}} \pm 0.42$ \\
\hline & \multicolumn{3}{|c|}{ Second planting date (May) } \\
\hline Gz 3B $\times$ Gz 15 & $16.50^{\mathrm{def}} \pm 0.00$ & $14.5^{\mathrm{f}}{ }_{\mathrm{b}} \pm 0.14$ & $13.80^{\text {ef }}{ }_{b} \pm 0.28$ \\
\hline Gz 3B $\times$ Gz 20 & $16.30{ }^{\text {ef }}{ }_{\mathrm{a}} \pm 0.42$ & $14.5^{\mathrm{f}}{ }_{\mathrm{b}} \pm 0.00$ & $13.60 \mathrm{ef}_{\mathrm{b}} \pm 0.14$ \\
\hline \multirow[t]{2}{*}{ Gz 20×Gz 10} & $17.90_{a}^{a b c} \pm 0.14$ & $16.00_{b}^{d} \pm 0.00$ & $16.00^{c}{ }_{b} \pm 0.00$ \\
\hline & \multicolumn{3}{|c|}{ Third date planting date(August) } \\
\hline Gz 3B $\times$ Gz 15 & $17.10_{\mathrm{a}}^{\mathrm{cde}} \pm 0.14$ & $16.50^{\mathrm{c}}{ }_{\mathrm{ab}} \pm 0.14$ & $16.25 \mathrm{~b}_{\mathrm{b}}^{\mathrm{c}} \pm 0.07$ \\
\hline Gz 3B $\times \mathbf{G z} 20$ & $18.05_{\mathrm{a}}^{\mathrm{ab}} \pm 0.21$ & $17.10_{b}^{b} \pm 0.14$ & $16.90 \mathrm{a}_{\mathrm{b}}^{\mathrm{b}} \pm 0.00$ \\
\hline Gz 20×Gz 10 & $18.20^{\mathrm{a}}{ }_{\mathrm{a}} \pm 0.28$ & $17.65_{\mathrm{ab}}^{\mathrm{a}} \pm 0.21$ & $17.30^{\mathrm{a}}{ }_{\mathrm{b}} \pm 0.00$ \\
\hline
\end{tabular}

$1^{\text {st }}=$ harvesting after 20 days from pollination, $2^{\text {nd }}=$ harvesting after 23 days from pollination and $3^{\text {rd }}=$ harvesting after 26 from pollination. Mean values followed by different superscripts (within the same column) and different subscripts (within the same row) are significantly different at the $5 \%$ level. Values are average of 3 experiments \pm SD.

\section{Total sugar content}

The results of total sugar content of sweet corn hybrids are illustrated in Table (7). The analysis showed significant differences between sweet corn hybrids at the different planting and harvesting dates. In the first planting date, sugar content decreased by increasing the harvest date for the three studied hybrids. The highest level was found in Gz20×Gz10 hybrid. Same trend was observed in the second planting date. The third planting date exhibited increase in the sugar content for three sweet corn hybrids, where reaching its maximum values $(7.59$, 7.39 and $6.14 \%$ ) in $\mathrm{Gz} 20 \times \mathrm{Gz} 10, \mathrm{Gz} 3 \mathrm{~B} \times \mathrm{G} 20$ and $\mathrm{Gz}$ $3 \mathrm{~B} \times \mathrm{Gz} 15$ hybrids, respectively at the first harvest date. Sugary varieties can lose their kernel quality rapidly after harvest due to the conversion of sugars to starch and moisture loss (Alan et al., 2014). Kernel sugar concentration attained its peak at 20 days after pollination (DAP) and gradually dropped off between 20 and 28 DAP (Szymanek, 2009).

\section{HPLC sugar fractionation}

HPLC sugar fractionations are shown in Table (8). Data cleared that sucrose is the main sugar in sweet corn kernels hybrids followed by fructose and glucose, respectively. A high value of sucrose was found in $\mathrm{Gz}$ $20 \times \mathrm{Gz} 10(6.82 \%)$ compared with $\mathrm{Gz} 3 \mathrm{~B} \times \mathrm{Gz} 15$ and $\mathrm{Gz}$ $3 \mathrm{~B} \times \mathrm{Gz} 20$ hybrids (5.45 and 6.55\%), respectively. Meanwhile, fructose content ranged from 0.28 to $0.36 \%$. The hybrid Gz $20 \times \mathrm{Gz} 10$ had the highest content $(0.36 \%)$, while hybrid Gz3B $\times \mathrm{Gz} 15$ had the lowest value $(0.28 \%)$. Glucose content ranged from 0.11 to $0.14 \%$ and the highest value recorded in $\mathrm{Gz} 3 \mathrm{~B} \times \mathrm{Gz} 20$ hybrid $(0.15 \%)$ followed by Gz20 $\times$ Gz10 hybrid (0.14\%). Results were similar with Nunes et al., (2013). Sucrose is the predominant sugar in sweet corn hybrids, accounting for approximately $77 \%$ to $94 \%$ of the mean total sugars content. Sucrose increased from trace amounts in unpollinated values to maximum levels at approximately 21 to 28 day post pollination. This difference persisted in the later stages of development (Shaw and Dickinson, 1984). 
Table (7): Total sugar content (as wet basis) of sweet corn hybrids at different three planting date and three harvesting date

\begin{tabular}{|c|c|c|c|}
\hline \multirow{3}{*}{ Hybrids } & \multicolumn{3}{|c|}{ Harvest date } \\
\hline & $1^{\text {st }}$ & $2^{\text {nd }}$ & $3^{\text {rd }}$ \\
\hline & \multicolumn{3}{|c|}{ First planting date (March) } \\
\hline Gz 3B $\times$ Gz 15 & $5.68^{\mathrm{g}}{ }_{\mathrm{a}} \pm 0.02$ & $3.81^{\mathrm{f}}{ }_{\mathrm{b}} \pm 0.00$ & $3.22^{\mathrm{g}} \mathrm{c} \pm 0.02$ \\
\hline Gz 3B $\times$ Gzz 20 & $6.16^{\mathrm{d}}{ }_{\mathrm{a}} \pm 0.06$ & $4.59^{\mathrm{e}}{ }_{\mathrm{b}} \pm 0.05$ & $3.58{ }_{c}^{\mathrm{f}} \pm 0.04$ \\
\hline \multirow[t]{2}{*}{ Gz 20×Gz 10} & $7.03^{\mathrm{c}}{ }_{\mathrm{a}} \pm 0.00$ & $6.99^{b}{ }_{a} \pm 0.09$ & $6.47^{c}{ }_{b} \pm 0.08$ \\
\hline & \multicolumn{3}{|c|}{ Second planting date (May) } \\
\hline Gz 3B $\times$ Gz 15 & $5.74_{\mathrm{a}}^{\mathrm{f}} \pm 0.02$ & $3.46^{\mathrm{g}}{ }_{\mathrm{b}} \pm 0.13$ & $3.00_{\mathrm{c}}^{\mathrm{g}} \pm 0.0$ \\
\hline Gz 3B $\times \mathbf{G z} 20$ & $5.98^{\mathrm{e}}{ }_{\mathrm{a}} \pm 0.02$ & $4.58^{\mathrm{e}}{ }_{\mathrm{b}} \pm 0.00$ & $3.62{ }_{c}^{\mathrm{f}} \pm 0.01$ \\
\hline \multirow[t]{2}{*}{ Gz $20 \times G z 10$} & $7.42^{b}{ }_{a} \pm 0.04$ & $6.74^{\mathrm{c}}{ }_{\mathrm{b}} \pm 0.02$ & $6.67_{\mathrm{c}}^{\mathrm{b}} \pm 0.00$ \\
\hline & \multicolumn{3}{|c|}{ Third date planting date (August) } \\
\hline Gz $3 B \times G z 15$ & $6.14^{\mathrm{d}}{ }_{\mathrm{a}} \pm 0.04$ & $5.57^{\mathrm{d}}{ }_{\mathrm{b}} \pm 0.02$ & $5.12{ }_{\mathrm{c}}^{\mathrm{e}} \pm 0.18$ \\
\hline Gz 3B $\times$ Gz 20 & $7.39^{b}{ }_{a} \pm 0.03$ & $6.77^{\mathrm{c}}{ }_{\mathrm{b}} \pm 0.09$ & $5.82{ }_{c}^{d} \pm 0.10$ \\
\hline Gz 20×Gz 10 & $7.59^{\mathrm{a}}{ }_{\mathrm{a}} \pm 0.02$ & $7.49^{\mathrm{a}}{ }_{\mathrm{b}} \pm 0.00$ & $7.33^{\mathrm{a}} \mathrm{c} \pm 0.01$ \\
\hline \multirow{2}{*}{\multicolumn{4}{|c|}{$\begin{array}{l}1^{\text {st }}=\text { harvesting after } 20 \text { days from pollination, } 2^{\text {nd }}=\text { harvesting after } 23 \text { days from pollination and } 3^{\text {rd }}=\text { harvesting after } 2 \\
\text { pollination Mean values followed by different superscripts (within the same column) and different subscripts (within the san } \\
\text { are significantly different at the } 5 \% \text { level. Values are average of } 3 \text { experiments } \pm S D \\
\text { Table (8): Sucrose, fructose and glucose content ( } \% \text { as wet basis) of sweet corn hybrids at third planting and first } \\
\text { harvest date }\end{array}$}} \\
\hline & & & \\
\hline Hybrids & Sucrose & Fructose & Glucose \\
\hline Gz 3B $\times \mathbf{G z} 15$ & 5.45 & 0.28 & 0.11 \\
\hline Gz 3B $\times$ Gz 20 & 6.55 & 0.31 & 0.15 \\
\hline Gz 20×Gz10 & 6.82 & 0.36 & 0.14 \\
\hline
\end{tabular}

\section{Starch content}

Starch content of sweet corn hybrids was presented in Table (9). Starch content increased by increasing harvest date in the three sweet corn hybrids. Hybrids $\mathrm{Gz} 3 \mathrm{~B} \times \mathrm{Gz} 15$ and $\mathrm{Gz} 3 \mathrm{~B} \times \mathrm{Gz} 20$ at the first and second planting date exhibited a similar starch content, while with no significant differences $(5 \%)$ between them in the third harvesting date $(21.99,21.91$ and $21.98,21.93 \%$ ), respectively. Low starch content was obtained in the third planting date for the three sweet corn hybrids compared with the first and second planting dates, the lowest value was found in hybrid Gz20× Gz10 compared with the other two hybrids. It could be observed that the planting and harvest dates affected on moisture, TSS, sugars and starch contents of sweet corn.

In general, the results showed, that delaying the harvest date decreasing the moisture and sugar contents and lead to an increase in the starch concentrations.
Negative associations between sugar content and starch content were observed by Ha (1999) and Kumari et al. (2006). Szymanek (2009) reported that during the period when sweet corn ears were suitable for harvesting and the kernel moisture was decreasing, total sugars content decreased from 6.24 to $5.11 \%$ and the starch content increased from 14.49 to $22.19 \%$. The mean values of total sugars and starch were not significantly different only between $1^{\text {st }}$ and $2^{\text {nd }}$ harvest dates.

\section{Color characteristics of fresh sweet corn kernels}

Table (10) represented the color measurements of sweet corn hybrids for the tested three planting dates at three different harvest dates. It could be noticed a decrease in lightness values was found as increasing the harvest date for the tasted three sweet corn hybrids. Hybrid Gz3B $\times$ Gz15 recorded the highest lightness values at the three planting dates and the lowest values were recorded in $\mathrm{Gz} 20 \times \mathrm{Gz} 10$ hybrid. In addition, increasing in the redness values $(a)$ and yellowness $(b)$ 
values by increasing the harvesting date at the three planting dates for three hybrids was observed. These indicated that after the three planting of plantation with the tested three harvesting dates of the hybrids sweet corn became more darker by increasing of yellowness values and decreasing of the lightness values. This may be attributed to the moisture decrement as the harvest date delayed which concentrate the yellow pigments in corn grains. These changes in color can affect in food quality products. This may be attributed to many characteristics of corn including hardness differences, variation in thickness of the pericarp, and variation in glossiness of the pericarp. The color of corn kernels can be considerably different from white to yellow, orange, red, purple, and brown. Pigments responsible for the coloration have been reported in the pericarp, aleurone layer, endosperm, and scutellum (Floyd et al., 1995).

Kernel lightness values were non significantly affected by varieties. Mean values ranged from 69.9 to 77.7. Significant differences $(p<0.01)$ were found in kernel chroma values between varieties (Alan et al.,
2014). Geeta et al. (2017) found that, the color values of $L^{*}, a^{*}$ and $b^{*}$ of sweet corn were $74.74,0.78$ and 49.18, respectively. The visual aspect of products destined to human consumption is of fundamental importance for their commercialization (Pinho et al., 2011).

\section{Total carotenoids content}

Carotenoids have antioxidant functions in plant photosynthetic processes, as well as in actions of disease reduction in mammalian systems (Luana et al., 2017). Table (11) showed the effect of different planting and harvesting dates on the carotenoids content in the sweet corn hybrids. Data showed a gradual increase in carotenoids by delaying the harvesting date in all hybrids. There are significant differences in carotenoids (5\% level) between the tested three hybrids of sweet corn $(\mathrm{Gz} 3 \mathrm{~B} \times \mathrm{Gz} 15, \mathrm{Gz} 3 \mathrm{~B} \times \mathrm{Gz} 20$ and $\mathrm{Gz} 20 \times \mathrm{Gz} 10)$ at different plating and different harvesting dates. At the first planting date, total carotenoides ranged from 4.94 to $9.80 \mathrm{ppm}, \mathrm{Gz} 20 \times \mathrm{Gz} 10$ hybrid had the highest value.

Table (9): Starch content ( $\%$ as wet basis) of sweet corn hybrids at different three planting and harvest dates

\begin{tabular}{|c|c|c|c|}
\hline \multirow{3}{*}{ Hybrids } & \multicolumn{3}{|c|}{ Harvest date } \\
\hline & $1^{\text {st }}$ & $2^{\text {nd }}$ & $3^{\text {rd }}$ \\
\hline & \multicolumn{3}{|c|}{ First planting date (March) } \\
\hline Gz 3B $\times$ Gz 15 & $19.87_{\mathrm{c}}^{\mathrm{c}} \pm 0.05$ & $20.24^{c}{ }_{b} \pm 0.07$ & $21.99^{a}{ }_{a} \pm 0.02$ \\
\hline Gz 3B $\times$ Gz 20 & $18.26^{\mathrm{d}}{ }_{\mathrm{c}} \pm 0.03$ & $19.99^{d}{ }_{b} \pm 0.03$ & $21.91_{\mathrm{a}}^{\mathrm{a}} \pm 0.00$ \\
\hline \multirow[t]{2}{*}{ Gz $20 \times G z 10$} & $15.90_{\mathrm{c}}^{\mathrm{f}} \pm 0.01$ & $17.18_{b}^{f} \pm 0.01$ & $18.13^{\mathrm{c}}{ }_{\mathrm{a}} \pm 0.12$ \\
\hline & \multicolumn{3}{|c|}{ Second planting date (May) } \\
\hline Gz 3B $\times$ Gz 15 & $20.92^{\mathrm{a}}{ }_{\mathrm{b}} \pm 0.05$ & $21.96^{\mathrm{a}} \mathrm{a} \pm 0.00$ & $21.98^{\mathrm{a}}{ }_{\mathrm{a}} \pm 0.00$ \\
\hline $\mathbf{G z 3 B} \times \mathbf{G z} 20$ & $20.00_{c}^{b} \pm 0.03$ & $20.99^{b}{ }_{b} \pm 0.03$ & $21.93^{\mathrm{a}}{ }_{\mathrm{a}} \pm 0.03$ \\
\hline Gz $20 \times$ Gz10 & $17.50{ }^{\mathrm{e}}{ }_{\mathrm{c}} \pm 0.03$ & $18.15^{\mathrm{e}}{ }_{\mathrm{b}} \pm 0.03$ & $18.46^{b}{ }_{a} \pm 0.12$ \\
\hline
\end{tabular}

Third date planting date(August)

\begin{tabular}{|c|c|c|c|}
\hline Gz $3 B \times G z 15$ & $15.29^{\mathrm{g}} \pm 0.01$ & $16.44^{\mathrm{g}}{ }_{\mathrm{b}} \pm 0.10$ & $17.01_{\mathrm{a}}^{\mathrm{d}} \pm 0.03$ \\
\hline Gz $3 B \times G z 20$ & $13.05_{\mathrm{c}}^{\mathrm{h}} \pm 0.00$ & $14.20^{\mathrm{h}}{ }_{\mathrm{b}} \pm 0.00$ & $14.911_{\mathrm{a}}^{\mathrm{e}} \pm 0.03$ \\
\hline Gz 20×Gz 10 & $12.57^{\mathrm{i}}{ }_{\mathrm{c}} \pm 0.03$ & $13.00^{\mathrm{i}}{ }_{\mathrm{b}} \pm 0.01$ & $13.38{ }^{\mathrm{f}}{ }_{\mathrm{a}} \pm 0.07$ \\
\hline
\end{tabular}

$1^{\text {st }}=$ harvesting after 20 days from pollination, $2^{\text {nd }}=$ harvesting after 23 days from pollination and $3^{\text {rd }}=$ harvesting after 26 from pollination. Mean values followed by different superscripts (within the same column) and different subscripts (within the same row) are significantly different at the $5 \%$ level. Values are average of 3 experiments $\pm \mathrm{SD}$ 
Table (10): Color characteristics of fresh sweet corn kernels at different planting and harvesting dates

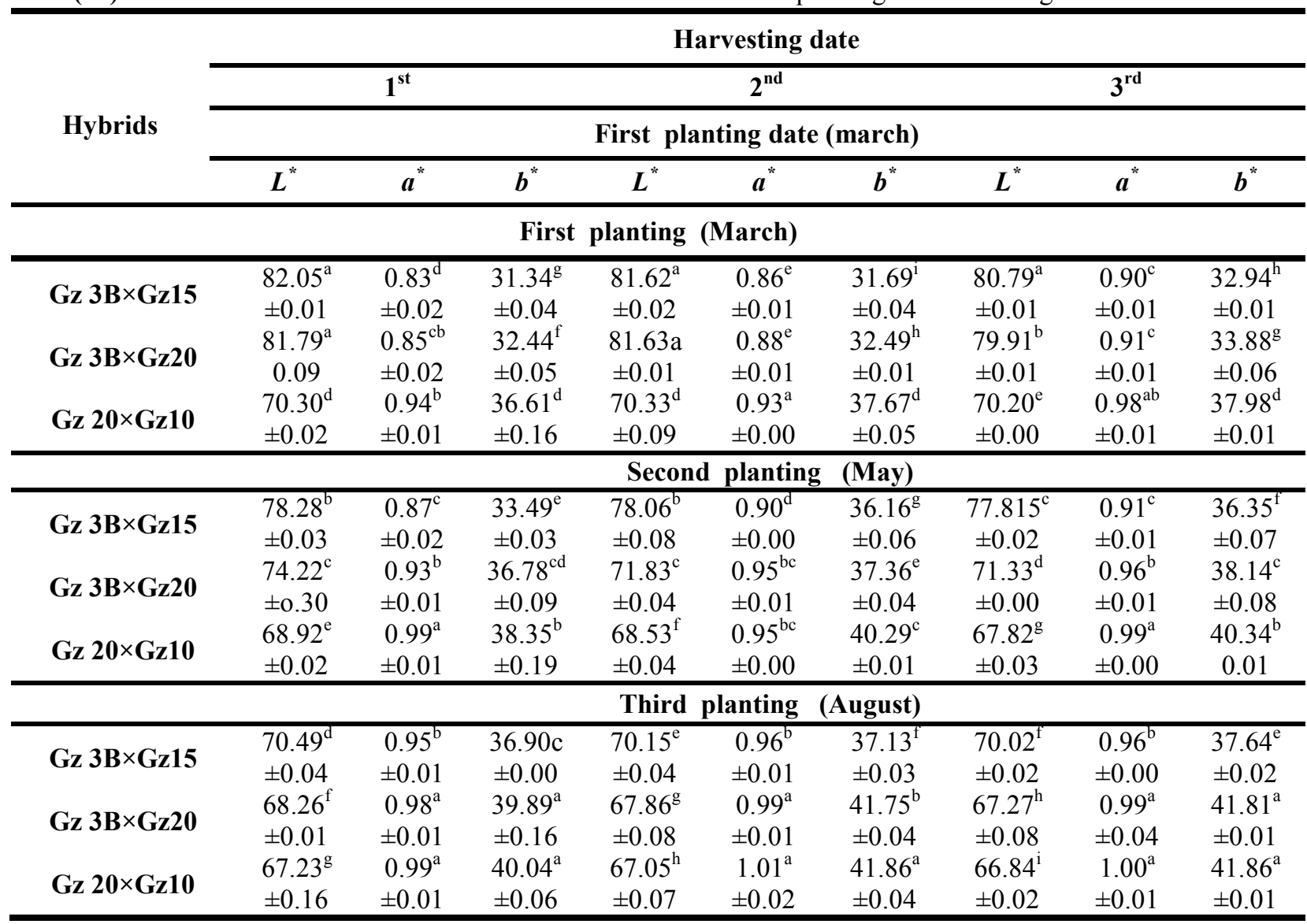

Mean values followed by different superscripts (within the same column) are significantly different at the $5 \%$ level. Values are average of 3 experiments \pm SD

Table (11): Total carotenoids content (ppm as wet basis) of sweet corn hybrids at different three planting and harvest dates

\begin{tabular}{|c|c|c|c|}
\hline \multirow{2}{*}{ Hybrids } & \multicolumn{3}{|c|}{ Harvest date } \\
\hline & $1^{\text {st }}$ & $2^{\text {nd }}$ & $3^{\text {rd }}$ \\
\hline & \multicolumn{3}{|c|}{ First planting date (March) } \\
\hline Gz 3B $\times$ Gz 15 & $4.94_{\mathrm{c}}^{\mathrm{h}} \pm 0.13$ & $5.59^{\mathrm{i}}{ }_{\mathrm{b}} \pm 0.13$ & $6.90{ }^{\mathrm{h}}{ }_{\mathrm{a}} \pm 0.04$ \\
\hline Gz $3 B \times G z 20$ & $5.30^{\mathrm{g}}{ }_{\mathrm{c}}^{ \pm} 0.01$ & $5.91^{\mathrm{h}}{ }_{\mathrm{b}} \pm 0.03$ & $6.99^{\mathrm{h}}{ }_{\mathrm{a}} \pm 0.00$ \\
\hline \multirow[t]{2}{*}{ Gz $20 \times$ Gz 10} & $8.31_{b^{ \pm}}^{\mathrm{e}} \pm 0.04$ & $9.77^{\mathrm{f}}{ }_{\mathrm{a}} \pm 0.04$ & $9.80{ }_{a}^{\mathrm{f}} \pm 0.05$ \\
\hline & \multicolumn{3}{|c|}{ Second planting date (May) } \\
\hline Gz $3 B \times G z 15$ & $7.85^{\mathrm{f}} \pm 0.07$ & $8.15^{\mathrm{g}}{ }_{\mathrm{b}} \pm 0.04$ & $8.78^{\mathrm{g}}{ }_{\mathrm{a}} \pm 0.04$ \\
\hline $\mathbf{G z} 3 \mathbf{3 B} \times \mathbf{G z} 20$ & $9.65_{b}^{d} \pm 0.07$ & $10.60_{\mathrm{a}}^{\mathrm{e}} \pm 0.00$ & $10.55^{\mathrm{e}} \mathrm{a} \pm 0.07$ \\
\hline \multirow[t]{2}{*}{ Gz $20 \times G z 10$} & $11.63^{\mathrm{b}}{ }_{\mathrm{b}} \pm 0.04$ & $11.75^{\mathrm{c}}{ }_{\mathrm{a}} \pm 0.03$ & $11.77_{\mathrm{a}}^{\mathrm{c}} \pm 0.04$ \\
\hline & \multicolumn{3}{|c|}{ Third planting date(August) } \\
\hline Gz $3 B \times G z 15$ & $10.62^{\mathrm{c}}{ }_{\mathrm{b}} \pm 0.02$ & $10.95^{\mathrm{d}}{ }_{\mathrm{a}} \pm 0.01$ & $10.98_{a}^{d} \pm 0.07$ \\
\hline $\mathbf{G z} 3 \mathbf{3 B} \times \mathbf{G z} 20$ & $11.85_{\mathrm{a}}^{\mathrm{a}} \pm 0.07$ & $11.91^{\mathrm{b}}{ }_{\mathrm{a}} \pm 0.08$ & $12.15^{\mathrm{b}}{ }_{\mathrm{a}} \pm 0.00$ \\
\hline Gz $20 \times \mathbf{G z} 10$ & $11.95^{\mathrm{a}} \pm 0.00$ & $12.19^{\mathrm{a}}{ }_{\mathrm{b}} \pm 0.05$ & $12.55^{\mathrm{a}} \mathrm{a} \pm 0.07$ \\
\hline
\end{tabular}

$1^{\text {st }}=$ harvesting after 20 days from pollination, $2^{\text {nd }}=$ harvesting after 23 days from pollination and $3^{\text {rd }}=$ harvesting after 26 from pollination. Mean values followed by different superscripts (within the same column) and different subscripts (within the same row) are significantly different at the $5 \%$ level. Values are average of 3 experiments $\pm \mathrm{SD}$ 
While at the second sowing date, carotenoids level ranged from 7.85 to $11.77 \mathrm{ppm}$. Higher carodenoids content is shown at the third sowing date for all studied hybrids. Luana et al. (2017) studied seven hybrids, the highest value recorded was $12.9 \mu \mathrm{g} / 100 \mathrm{~g}$. A high carotenoid content has been considered a primary characteristic to either increase the commercial value of a specific corn variety or select lines for genetic enhancement programs. Carotenes and xanthophylls are primarily responsible for the yellow color of corn (Pinho et al., 2011).

\section{Sensory evaluation}

The visual appearance is one of the main characteristics that affect the consumers' acceptance. Corn color may vary as a function of genetic origin, farming conditions, processing and storage (Pinho et al., 2011).

Table (12): Sensory evaluation of cooked sweet corn hybrids

\begin{tabular}{|c|c|c|c|c|c|}
\hline Hybrids & Appearance & Color & Flavor & Taste & $\begin{array}{l}\text { Overall- } \\
\text { acceptability }\end{array}$ \\
\hline Gz $3 B \times G z 15$ & $6.45^{\mathrm{b}} \pm 0.49$ & $7.65^{b} \pm 0.67$ & $7.45^{\mathrm{b}} \pm 0.49$ & $7.15^{\mathrm{b}} \pm 0.63$ & $7.0^{\mathrm{b}} \pm 0.41$ \\
\hline Gz $3 B \times G z 20$ & $8.60^{\mathrm{a}} \pm 0.66$ & $8.60^{\mathrm{a}} \pm 0.52$ & $8.60^{\mathrm{a}} \pm 0.46$ & $8.40^{\mathrm{a}} 0.74$ & $8.65^{\mathrm{a}} \pm 0.41$ \\
\hline Gz $20 \times$ Gz 10 & $8.85^{\mathrm{a}} \pm 0.24$ & $8.70^{\mathrm{a}} \pm 0.48$ & $8.65^{\mathrm{a}} \pm 0.47$ & $8.55^{\mathrm{a}} \pm 0.64$ & $8.70^{\mathrm{a}} \pm 0.35$ \\
\hline
\end{tabular}

Mean values followed by different superscripts (within the same column) are significantly different at the $5 \%$ level. Values are average of 10 plainest $\pm \mathrm{SD}$

Organoleptically sensory characteristics i.e. appearance, color, flavor, taste and overall acceptability of cooked sweet corn hybrids are shown in Table (12). The obtained data showed that, there were no significant differences in sensory characteristics between the two sweet corn hybrids $\mathrm{Gz} 3 \mathrm{~B} \times \mathrm{Gz} 20$ and $\mathrm{Gz} 20 \times \mathrm{Gz} 10$, which recorded the highest organoleptic points. The lowest values of all sensory characteristics were found in $\mathrm{Gz} 3 \mathrm{~B} \times \mathrm{Gz} 15$ hybrid.

Effect of frozen storage on changes of overall acceptability of the sweet corn hybrids

Overall acceptability of the tasted samples was evaluated during the frozen storage period ( 9 months) at $-18^{\circ} \mathrm{C}$ for the three sweet corn hybrids wrapped in polyethylene packages (Table 13). In general, the data showed a decrease in overall acceptability of sweet corn hybrids by increasing the storage time. No significant differences $(5 \%$ level) between $\mathrm{Gz} 3 \mathrm{~B} \times \mathrm{Gz} 20$ and $\mathrm{Gz}$ $20 \times \mathrm{Gz} 10$ hybrids until the first six months of storage. After this period, significant differences were evident. The hybrid Gz $20 \times \mathrm{Gz} 10$ of sweet corn recorded the highest acceptability points throughout the course of storage. Shao and $\mathrm{Li}$ (2011) reported that, scores of appearance and aroma of sweet corn declined significantly after 20 days of storage at $-1^{\circ} \mathrm{C}$.

Table (13): Overall acceptability of sweet corn hybrids during frozen storage at $-18^{\circ} \mathrm{C}$

\begin{tabular}{|c|c|c|c|c|}
\hline \multirow{2}{*}{ Hybrids } & \multicolumn{4}{|c|}{ Storage time } \\
\hline & 0 time & 3 months & 6 months & 9 months \\
\hline Gz $3 B \times G z 15$ & $7.80_{\mathrm{a}}^{\mathrm{b}} \pm 1.03$ & $6.70_{b}^{b} \pm 0.95$ & $6.65^{b}{ }_{b c} \pm 0.47$ & $5.95^{c}{ }_{c} \pm 0.50$ \\
\hline Gz3B $\times$ Gz 20 & $8.65^{\mathrm{a}}{ }_{\mathrm{a}} \pm 0.41$ & $8.40^{\mathrm{a}}{ }_{\mathrm{a}} \pm 0.46$ & $7.70_{b}^{a} \pm 0.95$ & $6.65^{\mathrm{b}}{ }_{\mathrm{c}} \pm 0.47$ \\
\hline Gz 20×Gz 10 & $8.70_{\mathrm{a}}^{\mathrm{a}} \pm 0.42$ & $8.45_{\mathrm{ab}}^{\mathrm{a}} \pm 0.50$ & $7.95_{\mathrm{bc}}^{\mathrm{a}} \pm 0.76$ & $7.70^{\mathrm{a}}{ }_{\mathrm{c}} \pm 0.48$ \\
\hline
\end{tabular}

Mean values followed by different superscripts (within the same column) and different subscripts (within the same row) are significantly different at the $5 \%$ level. Values are average of 10 plainest $\pm \mathrm{SD}$

\section{Effect of frozen storage on sugar, starch and loss of weight changes of sweet corn hybrids}

Table (14) showed the changes of sugar, starch and the weight loss of the total selected sweet corn hybrids $(\mathrm{Gz} 3 \mathrm{~B} \times \mathrm{Gz} 15, \mathrm{Gz} 3 \mathrm{~B} \times \mathrm{Gz} 20$ and $\mathrm{Gz} 20 \times \mathrm{Gz}$ 10) during storage and freezing conditions. Data showed a decrease of sugar and starch as well as an increase in weight loss by increasing the storage period. Statistic analysis indicated significant differences in sugar content among the tested three hybrids of sweet corn during storage period and the Gz $20 \times \mathrm{Gz} 10$ hybrid of sweet corn showed a high level of the sugar content. A high level of starch was recorded for $\mathrm{Gz} 3 \mathrm{~B} \times \mathrm{Gz} 15$ during the storage. Non significant differences were showed between $\mathrm{Gz} 3 \mathrm{~B} \times \mathrm{Gz} 20$ and $\mathrm{Gz} 20 \times \mathrm{Gz} 10$ at 6 and 9 months of frozen storage. 
Table (14): Effect of frozen storage on sugar, starch and weight losses changes of sweet corn hybrids

Storage time (months)

\begin{tabular}{|c|c|c|c|c|}
\hline \multirow[t]{2}{*}{ Hybrids } & $\mathbf{O}$ & 3 & 6 & 9 \\
\hline & \multicolumn{4}{|c|}{ Sugar } \\
\hline Gz 3B $\times \mathbf{G z} 15$ & $5.81_{\mathrm{a}}^{\mathrm{c}} \pm 0.02$ & $5.21^{\mathrm{c}}{ }_{\mathrm{b}} \pm 0.03$ & $4.56^{\mathrm{c}}{ }_{\mathrm{c}} \pm 0.04$ & $3.96_{\mathrm{d}}^{\mathrm{c}} \pm 0.01$ \\
\hline Gz 3B × Gz 20 & $6.87_{\mathrm{a}}^{\mathrm{b}} \pm 0.02$ & $6.80_{\mathrm{a}}^{\mathrm{b}} \pm 0.04$ & $5.76_{\mathrm{b}}^{\mathrm{b}} \pm 0.02$ & $5.33^{\mathrm{b}}{ }_{\mathrm{c}} \pm 0.07$ \\
\hline \multirow[t]{2}{*}{ Gz 20×Gz 10} & $7.09^{\mathrm{a}}{ }_{\mathrm{a}} \pm 0.03$ & $7.06_{\mathrm{a}}^{\mathrm{a}} \pm 0.00$ & $6.20_{\mathrm{b}}^{\mathrm{a}} \pm 0.03$ & $6.16^{\mathrm{a}}{ }_{\mathrm{b}} \pm 0.0$ \\
\hline & \multicolumn{4}{|c|}{ Starch } \\
\hline Gz 3B $\times$ Gz 15 & $13.03^{\mathrm{a}}{ }_{\mathrm{a}} \pm 0.04$ & $12.82^{\mathrm{a}}{ }_{\mathrm{a}} \pm 0.05$ & $12.57^{\mathrm{a}} \pm 0.03$ & $11.64^{\mathrm{a}}{ }_{\mathrm{c}} \pm 0.08$ \\
\hline Gz 3B $\times$ Gz 20 & $11.56^{\mathrm{b}}{ }_{\mathrm{a}} \pm 0.00$ & $11.34^{b}{ }_{b} \pm 0.06$ & $10.93^{\mathrm{b}} \pm 0.07$ & $10.88^{\mathrm{ab}}{ }_{\mathrm{c}} \pm 0.01$ \\
\hline \multirow[t]{2}{*}{ Gz 20×Gz 10} & $11.27^{\mathrm{c}}{ }_{\mathrm{a}} \pm 0.02$ & $11.17^{\mathrm{b}}{ }_{\mathrm{a}} \pm 0.02$ & $10.85^{b}{ }_{b} \pm 0.06$ & $10.55^{\mathrm{b}}{ }_{\mathrm{c}} \pm 0.17$ \\
\hline & \multicolumn{4}{|c|}{ Weight loss } \\
\hline Gz 3B $\times \mathbf{G z} 15$ & $0.33^{\mathrm{a}}{ }_{\mathrm{c}} \pm 0.02$ & $0.33^{\mathrm{a}}{ }_{\mathrm{c}} \pm 0.12$ & $0.89^{\mathrm{a}}{ }_{\mathrm{b}} \pm 0.00$ & $1.44_{\mathrm{a}}^{\mathrm{a}} \pm 0.00$ \\
\hline Gz 3B $\times$ Gz 20 & $0.09^{\mathrm{b}}{ }_{\mathrm{c}} \pm 0.01$ & $0.09^{\mathrm{b}}{ }_{\mathrm{c}} \pm 0.01$ & $0.50_{\mathrm{b}}^{\mathrm{b}} \pm 0.01$ & $0.98_{\mathrm{a}}^{\mathrm{b}} \pm 0.01$ \\
\hline $\mathbf{G z} 20 \times \mathbf{G z} 10$ & $0.07_{\mathrm{c}}^{\mathrm{b}} \pm 0.03$ & $0.07_{c}^{b} \pm 0.03$ & $0.45^{\mathrm{b}}{ }_{\mathrm{b}} \pm 0.00$ & $0.98^{b}{ }_{a} \pm 0.01$ \\
\hline
\end{tabular}

*Mean values followed by different superscripts (within the same column for the same parameter) and different subscripts (within the same row) are significantly different at the $5 \%$ value. Values are the average of 3 experiments \pm SD

At the first three months of frozen storage no significant differences in weight loss were recorded for the tested three sweet corn hybrids but an increase in weight loss at 6 and 9 months of frozen storage were found. Statistic of analysis data recorded non significant differences between $\mathrm{Gz} 3 \mathrm{~B} \times \mathrm{Gz} 20$ and $\mathrm{Gz} 20 \times \mathrm{Gz} 10$ during the frozen storage. In general, the sugar content of fresh kernels was higher than frozen for all varieties. The starch content of the varieties was decreased after freezing storage.

Shao and $\mathrm{Li}$ (2011) found that, there was a slight decrease after 5 days of storage at $-1^{\circ} \mathrm{C}$ then, a slight increase was observed until day 15 and finally, a sharp fall was detected by day 20 and day 25 . Sugar, as one of osmotic active substances, can be induced by cold stress, so sugar content increased after 5 days (Galindo et al., 2007). Shao and $\mathrm{Li}$ (2011) reported that, sweet corn had low sugar losing rate, losing 2.8 and 10.4 and $7.6 \%$ by day 20 , losing $24.3,28.1$ and $29.3 \%$ by day 25 for unpackaged, packaged and packaged + cold acclimation $(\mathrm{CA})$ at $-1^{\circ} \mathrm{C}$, respectively, when compared with fresh corn.

Weight loss of unpackaged corns increased dramatically, while that of packaged increased a little. The decrease of moisture content of corn kernel was slow, but the weight loss of unpackaged was faster than those of the packaged. The phenomenon indicated that perforated packaged bag can prevent the water loss, which is mainly from the husk (Shao and Li, 2011).

Effect of frozen storage on carotenoid changes of sweet corn hybrids

Table (15) presented the carotenoid contents of the selected three sweet corn hybrids $\mathrm{Gz} 3 \mathrm{~B} \times \mathrm{Gz} 15$, GA $3 \mathrm{~B} \times \mathrm{Gz} 20$ and $\mathrm{Gz} 20 \times \mathrm{Gz} 10$ during frozen storage ($18 \mathrm{C}^{\circ}$ ) during nine months. All frozen sweet corn increased in total carotenoid contents compared with raw sweet corn in Table (10). At zero time, $\mathrm{Gz} 3 \mathrm{~B} \times \mathrm{Gz}$ 20 and $\mathrm{Gz} 20 \times \mathrm{Gz} 10$ hybrids nearly showed the same carotenoids content (38.81 and $38.93 \mathrm{ppm}$ ) while the $\mathrm{Gz}$ $3 \mathrm{~B} \times \mathrm{Gz} 15$ hybrid showed the lowest level (34.77 ppm). After 3, 6 and 9 months of storage, carotenoids content showed non significantly decrease in the studied hybrids $(\mathrm{Gz} 3 \mathrm{~B} \times \mathrm{Gz} 20$ and $\mathrm{Gz} 20 \times \mathrm{Gz} 10)$. In addition, there were significant differences between $\mathrm{Gz} 3 \mathrm{~B} \times \mathrm{Gz} 15$ and the other two hybrids $(\mathrm{Gz} 3 \mathrm{~B} \times \mathrm{Gz} 20$ and $\mathrm{Gz} 20 \times \mathrm{Gz} 10)$. Junpatiw et al., (2013) reported that, blanched sweet corn cultivars had highest lutein, zeaxanthin, ßcryptoxanthin and total carotenoid contents compared to raw sweet corns. 
Table (15): Effect of frozen storage on total carotenoid content (ppm as wet basis) in sweet corn hybrid

\begin{tabular}{|c|c|c|c|c|}
\hline \multirow{2}{*}{ Samples } & \multicolumn{4}{|c|}{ Storage time (months) } \\
\hline & $\mathbf{O}$ & 3 & 6 & 9 \\
\hline Gz 3B $\times$ Gz 15 & $34.77_{\mathrm{a}}^{\mathrm{c}} \pm 0.01$ & $33.32^{\mathrm{b}}{ }_{\mathrm{b}} \pm 0.00$ & $31.52^{\mathrm{b}} \mathrm{c} \pm 0.00$ & $31.44_{\mathrm{d}}^{\mathrm{b}} \pm 0.01$ \\
\hline Gz $3 B \times G z 20$ & $38.81_{\mathrm{a}}^{\mathrm{b}} \pm 0.02$ & $37.19_{\mathrm{b}}^{\mathrm{a}} \pm 0.00$ & $36.72^{\mathrm{a}} \mathrm{c} \pm 0.06$ & $36.58^{a}{ }_{d} \pm 0.03$ \\
\hline Gz 20×Gz 10 & $38.93^{\mathrm{a}}{ }_{\mathrm{a}} \pm 0.02$ & $37.20_{\mathrm{b}}^{\mathrm{a}} \pm 0.01$ & $36.75^{\mathrm{a}}{ }_{\mathrm{c}} \pm 0.02$ & $36.64^{\mathrm{a}}{ }_{\mathrm{d}} \pm 0.10$ \\
\hline
\end{tabular}

Mean values followed by different superscripts (within the same column) and different subscripts (within the same row) are significantly different at the $5 \%$ level. Values are average of 3 experiments \pm SD

The increase in lutein, zeaxanthin and $\beta$ cryptoxanthin may be due to the release of bound carotenoids from the food matrix as a result of blanching. The loss of other soluble solids during blanching and cooking could account for increase in the carotenoid contents (Booth, 1992). The inactivation of peroxidase and lipoxygenase activities involved in carotenoid destruction could be a reason for the retention of carotenoids (Junpatiw et al., 2013).

\section{Effect of frozen storage on color changes of sweet corn hybrids}

Table (16) showed the color measurements of frozen sweet corn hybrids for 9 months at $-18^{\circ} \mathrm{C}$. Concerning to GA $3 \mathrm{~B} \times \mathrm{Gz} 20$ and $\mathrm{Gz} 20 \times \mathrm{Gz} 10$ hybrids the results cleared that no significant differences noted for $L^{*}$ values component during the storage period from three months to the end of storage. Significant differences were found between them at zero time. $\mathrm{Gz}$ $3 \mathrm{~B} \times \mathrm{Gz} 15$ recorded the highest value of lightness compared with other hybrids, and reduced in that value during the storage. The value was increased during storage for $\mathrm{Gz} 3 \mathrm{~B} \times \mathrm{Gz} 15$ and $\mathrm{Gz} 3 \mathrm{~B} \times \mathrm{Gz} 20$ hybrids where recorded 1.30 and 1.24 at the storage end compared with zero time which recorded 1.25 and 1.20, respectively. The values of $b^{*}$ indicates that, no significant differences in its values for hybrid Gz 20 $\times \mathrm{Gz} 10$ during storage period. The hybrid Gz3B $\times \mathrm{Gz} 15$ noted significant differences in its $b^{*}$ values during storage after three months of storage compared with $\mathrm{Gz}$ $3 \mathrm{~B} \times \mathrm{Gz} 20$, the significant differences in its value were appeared after six months of storage. Color changes give information about the extent of browning reaction such as enzymatic browning during storage time.

Corn color may vary as a function of genetic origin, farming conditions, processing and storage. A color of sweet corn is more desirable for product development and it was a direct measurement of its whiteness (Pinho et al, 2011).

Table (16): Effect of frozen storage on color changes of sweet corn hybrids

\begin{tabular}{|c|c|c|c|c|}
\hline $\begin{array}{c}\text { Storage period } \\
\text { (month) }\end{array}$ & Hybrids & $L^{*}$ & $a^{*}$ & $b^{*}$ \\
\hline \multirow{4}{*}{$\mathbf{0}$} & $\mathrm{Gz} 3 \mathrm{~B} \times \mathrm{Gz} 15$ & $68.54^{\mathrm{a}} \pm 0.16$ & $1.25^{\mathrm{ab}} \pm 0.02$ & $46.55^{\mathrm{d}} \pm 0.03$ \\
\hline & $\mathrm{Gz} 3 \mathrm{~B} \times \mathrm{Gz} 20$ & $65.77^{\mathrm{d}} \pm 0.30$ & $1.20^{\mathrm{ab}} \pm 0.00$ & $48.91^{\mathrm{b}} \pm 0.01$ \\
\hline & $\mathrm{Gz} 20 \times \mathrm{Gz} 10$ & $63.87^{b} \pm 0.09$ & $1.00^{\mathrm{cd}} \pm 0.13$ & $49.21^{\mathrm{a}} \pm 0.16$ \\
\hline & $\mathrm{Gz} 3 \mathrm{~B} \times \mathrm{Gz} 15$ & $67.87^{\mathrm{b}} \pm 0.09$ & $1.25^{\mathrm{ab}} \pm 0.01$ & $46.54^{\mathrm{d}} \pm 0.11$ \\
\hline \multirow{2}{*}{3} & $\mathrm{Gz} 3 \mathrm{~B} \times \mathrm{Gz} 20$ & $65.72^{d} \pm 0.37$ & $1.23^{\mathrm{ab}} \pm 0.03$ & $48.77^{b c} \pm 0.08$ \\
\hline & $\mathrm{Gz} 20 \times \mathrm{Gz} 10$ & $65.45^{\mathrm{d}} \pm 0.06$ & $1.03^{\mathrm{cd}} \pm 0.07$ & $49.20^{\mathrm{a}} \pm 0.16$ \\
\hline \multirow{4}{*}{6} & $\mathrm{Gz} 3 \mathrm{~B} \times \mathrm{Gz} 15$ & $67.46^{c} \pm 0.11$ & $1.29^{\mathrm{a}} \pm 0.02$ & $46.18^{\mathrm{e}} \pm 0.11$ \\
\hline & $\mathrm{Gz} 3 \mathrm{~B} \times \mathrm{Gz} 20$ & $65.74^{\mathrm{d}} \pm 0.01$ & $1.24^{b c} \pm 0.03$ & $48.77^{b c} \pm 0.00$ \\
\hline & $\mathrm{Gz} 20 \times \mathrm{Gz} 10$ & $65.40^{\mathrm{d}} \pm 0.06$ & $1.07^{\mathrm{cd}} \pm 0.02$ & $49.18^{\mathrm{a}} \pm 0.04$ \\
\hline & $\mathrm{Gz} 3 \mathrm{~B} \times \mathrm{Gz} 15$ & $66.87^{c} \pm 0.00$ & $1.30^{\mathrm{a}} \pm 0.05$ & $45.99^{\mathrm{e}} \pm 0.17$ \\
\hline \multirow{2}{*}{9} & $\mathrm{Gz} 3 \mathrm{~B} \times \mathrm{Gz} 20$ & $65.74^{\mathrm{d}} \pm 0.00$ & $1.24^{b c} \pm 0.05$ & $48.67^{\mathrm{c}} \pm 0.09$ \\
\hline & $\mathrm{Gz} 20 \times \mathrm{Gz} 10$ & $65.39^{\mathrm{d}} \pm 0.03$ & $1.06^{\mathrm{cd}} \pm 0.05$ & $49.19^{\mathrm{a}} \pm 0.03$ \\
\hline
\end{tabular}

Mean values followed by different superscripts (within the same column) are significantly different at the $5 \%$ level. Values are average of 3 experiments \pm SD 


\section{CONCLUSION}

One of the goals of sweet corn producers is to produce sweet corn with a high sugar concentration in the endosperm. In sweet corn, sweetness is the major component and is affected by the amounts of sugar and starch in the endosperm. Other characteristics of high quality sweet corn are tenderness and low starch content. The delay of the corn cobs harvest date affected the changes of moisture, sugars and starch content. The best planting date was august and the best harvest date was (20 days after pollination). Gz $20 \times \mathrm{Gz} 10$ hybrid showed a high level of sugar content. Sucrose is the main sugar in sweet corn kernels. Non significant differences between $\mathrm{Gz} 3 \mathrm{~B} \times \mathrm{Gz} 20$ and $\mathrm{Gz} 20 \times \mathrm{Gz} 10$ during frozen storage was observed.

\section{ACKNOWLEDGMENTS}

The authors would like to express gratitude to Field Crops Research Institute and Food Technology Research Institute, Agricultural Research Center for continuing cooperation to support research by intramural funding and provided facilities required to carry out the most wanted objectives of the research work. The authors would also like to thank the Prof. Tamer Saafan for his support during research stages and to Prof. Mona A.M. Ali for her help with scientific and linguistic copy editing.

\section{REFERENCES}

Abdul Rahman, A. M., E. L. Mogboul and E. N. Abdollatief (2001). Effects of sowing date and cultivar on the yield and yield components of sweet maizein Northern Sudan. Proceedings of the Seventh Eastern and Southern Africa. Regional Maize Conference, Feb. 11-15, Nairobi, Kenya, 295-298.

Alan, O., G. Kinacl, E. Kinacl, Z. B. Bascigtcl, Z. B. Basciftcl, K. Sonmez, Y. Evrenosoglu and I. Kutlu (2014). Kernel quality of some sweet corn varieties in relation to processing. Not. Bot. Horti. Agrobo., 42(2): 414-419.

AACC (2000). Approved methods of the AACC. $10^{\text {th }}$ ed. The Association: St. Paul. MN.

AOAC (2005) Official Methods of Analysis of AOAC International. $18^{\text {th }}$ ed. AOAC, Washington D.C.

Azanza, F., B. P. Klein and J. A. Juvik (1996). Sensory characterization of sweet corn lines differing in physical and chemical composition. J. Food Sci., 61: 253-257.

Booth, S. A. (1992). Nutrient content of selected indigenous leafy vegetables consumed by the Kekchi people of Alta Verapaz, Guatemala. J. Food Compos. Analysis, 3(1): 47-53.

Dewanto, V., X. Wu and R. H. Liu (2002). Processed sweet corn has higher antioxidant activity. J. Agric. Food Chem., 50(17): 4959-4964.

Floyd, C. D., L. W. Rooney and A. J. Bockholt (1995). Measuring desirable and undesirable color in white and yellow food corn. Cereal Chem., 72(5): 488-490.
Galindo, F. G., I. Sjöholm, A. G. Rasmusson, S. Widell and K. Kaack (2007). Plant stress physiology: Opportunities and challenges for the food industry. Crit. Rev. Food Sci., 47(8): 749-763.

Geeta, H. P., V. Palanlmuthu and G. Srinivas (2017). Study of some physic-chemical properties of sweet corn. Int. J. Agric. Sci. Res., 7(1): 277-286.

Ha, V. (1999). Genetic analysis of some yield components and kernel quality in sweet corn. Romania Agric. Res., 11-12: 9-20.

Hale, T. A., R. L. Hassell and T. Phillips (2005). Refractometer measurements of soluble solid concentration do not reliably predict sugar content in sweet corn. Hort. Technol., 15(3): 668672.

Hossain, F., T. Nepolean, A. K. Vishwakarma, N. Pandey, B. M. Prasanna and H. S. Gupta (2015). Mapping and validation of microsatellite markers linked to sugary1 and shrunken 2 genes in maize (Zea mays L.). J. Plant Biochem. Biotechnol., 24(2): 135-142.

Hamzeh, A. K., Z. Hossein and A. Akbar (2015). Effects of sowing date on yield and yield components in sweet maize (Zea mays L.) Hybrids. Biol. Int. J., 7(2): 835-840.

Jarvis, C. E. and J. R. L. Walker (1993). Simultaneous, rapid, spectrophotometric determination of total starch, amylase and amylopectine. J. Sci. F. Agric., 63: 53-57.

Junpatiw, A., K. Lertrat, K. Lomthaisong and R. Tangwongchai (2013). Effects of steaming, boiling and frozen storage on carotenoid contents of various sweet corn cultivars. Int. Food Res. J., 20(5): 2219-2225.

Jelena, S., P. Zorica and F. Milomir (2016). Sweet corn (Zea mays L.) fresh ear yield in dependence of genotype and the environment. Selekcija I Semenarstvo, 22: 27-32.

Kleinhenz, M. D. (2003). Sweet corn variety trials in Ohio: recent top performers and suggestions for future evaluations. Hort. Technol., 13(4): 711718.

Korunic, Z., P. G. Fields, M. I. Kovacs, J. S. Noll, O. M. Lukow, C. J. Demianyk, K. J. Shibley (1996). The effect of diatomaceous earth on grain quality. Postharvest Biol. Technol., 9: 373-387.

Kulvade, T. and T. Chowladda (1997). Effect of harvesting period on field and quality of annes whole kernel sweet corn. Food, 27: 248-254.

Kumari, J., R. N. Gadag and G. K. Jha (2006). Heritability and correlation studies in sweet corn for quality traits, field emergence and grain yield. M N L., 80:18-19.

Lee, J. K., J. Y. Park, J. H. Kim, S. J. Kwon, J. H. Shin, S. K. Hong, H. K. Min and N. S. Kim (2006). Genetic mapping of the Isaac-CACTA transpose on in maize. Theoretical and App. Genet., 113: 16-22.

Lertrat, K. and T. Pulam (2007). Breeding for increased sweetness in sweet corn. Int. J. Plant Breed, 1(1): 27-30.

Luana, G. P., M. Apahidean, V. Has, A. I. Apahidean and F. Russu (2017). Research on the quality of 
sweet corn hybrids grown under the conditions of transylvanian plain. Agric. Sci. Practice, (3-4): 103-104.

McGurie, R. G. (1992). Reporting of Objective Color Measurements. HortScience, 27: 1254-1255.

Nielson, R. L., P. R. Thomison, G. A. Brown, A. L., Halter, J. Wells and K. L. Wuethrich (2002). Delayed planting date effects on flowering and grain maturation of sweet corn. Agronomy J., 94: 549- 558.

Nunes, M. C. N., A. Delgado, Y. Yagiz and J. P. Emond (2013). Influence of field temperatures on the moisture and sugar contents of sweet corn. Proc. Fla. State Hort. Soc., 126: 243-246.

Pajić, Z., J. Srdić and M. Filipović (2008). Sweet maize breeding for different consumption purposes. J. On processing and energy in agriculture, 12: 1214.

Pinho, L., M. C. D. Paes, M. B. A. Gloria, A. C. Almeida and C. A. Costa (2011). Color and chemical composition and of green corn produced under organic and conventional conditions. Cienc. Tecnol. Aliment., Campinas, 31(2): 366-371.

Sadaiah, K., R. V. Narsimha and K. S. Sudheer (2013). Heterosis and Combining ability Studies for Sugar content in Sweet corn (Zea mays saccharata L.). Int. J. Sci. Res. Public., 3: 22503153.
Sa, K. J., J. Y. Park, K. C. Park and J. K. Lee (2012). Analysis of genetic mapping in a waxy/dent maize RIL population using SSR and SNP markers. Genes and Genomics, 34: 157-164.

SAS (1987). Statistical analysis system. Release 6.03.SAS Institute Inc. Carry, Nc. USA.

Scott, C. E. and A. L. Eldridge (2005). Comparison of carotenoid content in fresh, frozen and canned corn. J. Food Composition and Analysis, 18: $551-559$.

Shao, X. and Y. Li (2011). Quality control of fresh sweet corn in controlled freezing-point storage. African J. Biotech., 10(65): 14534-14542.

Shaw, J. R. and D. B. Dickinson (1984). Studies of Sugars and Sorbitol in Developing Corn Kernels. Plant Physiol., 75: 207-2.

Shin, J. H., S. J. Kwon, J. K. Lee, H. K. Min and N. S. Kim (2006). Genetic diversity of maize starchsynthesis genes with SNPs. Genome, 49: 12871296.

Szymanek, M. (2009). Influence of sweet corn harvest date on kernels quality. Res. Agric. Eng., 55 (1): $10-17$.

Turkmen, N., F. Sari and S. T. Velioglu (2005). The effect of cooking methods on total phenolics and antioxidant activity of selected green vegetables. Food Chem., 93: (4): 713-718.

\section{تقييم بعض هجن الذرة السكرية للصفات الزراعية والتكنولوجية تحت مواعيد زراعة مختلفة

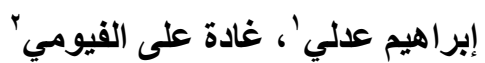

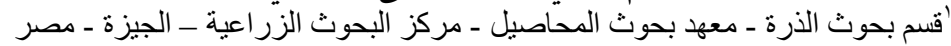

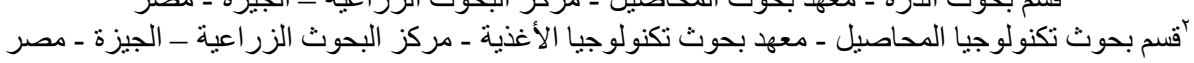

تزرع الذرة السكرية للاستخدام في الأسواق طازجة أو مصنعة. كانت الدراسة من خلال تجربتين ميدانيتين في محطة بمركز البحوث الزبن الزراعية

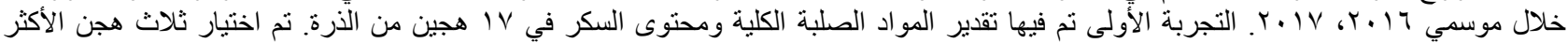

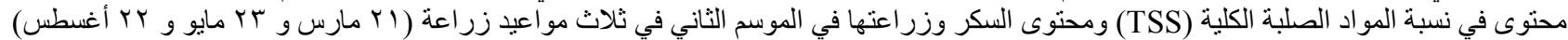

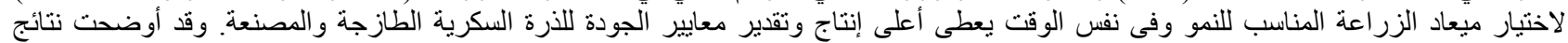

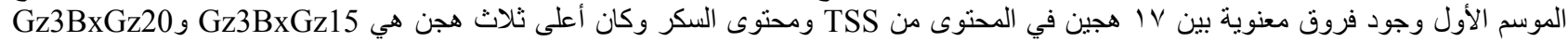

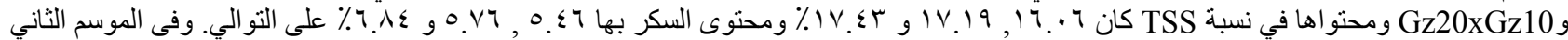

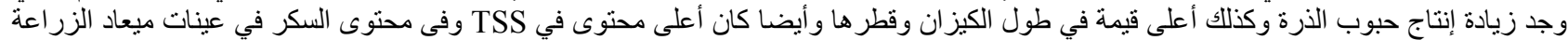

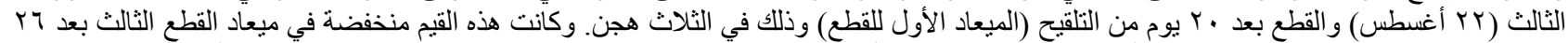

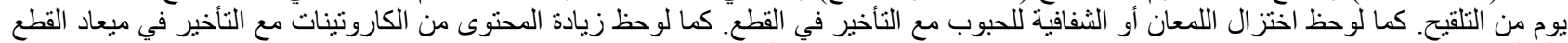

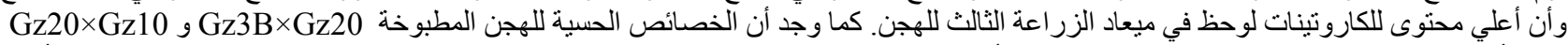

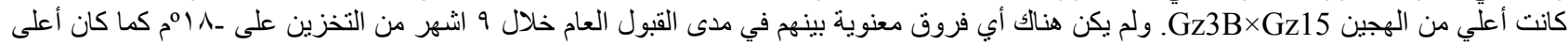

